\title{
Literature and the revolution.
}

\section{Guest editor introduction}

\section{Lina Steiner ${ }^{1}$}

Published online: 25 February 2019

(c) Springer Nature B.V. 2019

In this special issue we are continuing to publish essays that were originally presented at the conference "Russian Thinkers Between the Revolution and Tradition, 1880s-1920s" held at the International Centre for Philosophy, NRW at Bonn University, in October 2017. The topics of the essays included in this issue range from Leo Tolstoy's lifelong fascination with the Decembrists, whose powerful individualities inspired the writer's quest for ethical anarchism (Lina Steiner), to exploring the connection between revolutionary action and play as manifested by the revolutions of 1917-1918 in Russia and Germany (Julia Mehlich), to Nikolai Berdyaev's conception of theurgy and its relevance to contemporary philosophy of art (Vladimir Marchenkov), and to a reevaluation of Leo Tolstoy's and Maxim Gorky's overlapping perspectives on the socio-political and moral-spiritual situation in Russia on the eve of the 1917 revolution.

The overarching theme of this issue could be defined as "Literature and the Revolution," where "literature" means not only imaginative writing, but also literary criticism, as well as popular philosophical and publicist prose. This is, of course, a vast and popular topic. As is well known, Russian academic philosophy, which started to emerge only in the 1840s, was a latecomer on the country's intellectual scene. Prior to this period, which witnessed a veritable cult of German idealism on the Russian soil, most important questions pertaining to civic freedom and responsibility had been carried out in literary societies and salons as well as in literary almanacs and "thick journals." The first organized political movement in Russian history, the Decembrist movement, sprang from literary associations, most notably Arzamas and the Green Lamp. Like the political clubs in the pre-revolutionary Paris, these literary societies cultivated a new civic ideal of a morally self-determined and politically engaged personality (lichnost'). Promoted by such Decembrist poets and prose writers as Kondratii Ryleev, Fyodor Glinka, Alexander Odoevsky, Pavel Katenin and others, these values quickly took root in Russian literary discourse and continued to

Lina Steiner

lsteiner@uni-bonn.de

1 International Centre for Philosophy, University of Bonn, Poppelsdorfer Allee 28, 53115 Bonn, Germany 
thrive despite governmental repressions against the Decembrist movement. A circle of those involved in liberal literary associations was much wider than those involved in a political conspiracy. It included a number of first-rate authors whose careers were not destroyed but altered by the Decembrist fiasco of 1825. Thus, for example, the liberal tenor of Alexander Pushkin's youthful lyric poetry and of Alexander Griboyedov's comedy Woe from Wit, both written in the midst of the Decembrist upsurge, had a formative influence on the entire subsequent literary tradition thanks to these works' poetic brio which rendered them unforgettable. Pyotr Chaadaev, who is often considered as the first professional philosopher in Russia, was also close to the Decembrist circles, which left their ineffaceable stamp on both his thought and personality. Indeed, as Yurii Lotman has argued, the Decembrists' behavior in public and even in everyday life was highly self-conscious and conveyed a sense of autonomy. From this vantage point, Chaadaev's resignation from military service and his subsequent turn to philosophical prose writing appears as an ethically and politically charged step. ${ }^{1}$ Like ancient Stoics, for whom philosophy was neither merely a profession nor a method of thinking, but a way of life, Chaadaev saw philosophy as the venue for cultivating individuality in a country that he characterized as faceless and devoid of depth.

The scandal surrounding the publication of Chaadaev's First Philosophical Letter catalyzed a great debate about Russia's identity and role in world history, which led to a split between the Slavophiles and Westernizers. Thus, having publicly accused his fellow countrymen of their inability to think philosophically and to accrue historical experience, Chaadaev ushered in the most remarkable decade in the Russian intellectual history, which became a marvel for Europe and the entire world. This decade witnessed the emergence of some of Russia's preeminent novelists, including Ivan Turgenev, Fyodor Dostoevsky, Ivan Goncharov, as well as of a number of daring critical and philosophical minds, such as Vissarion Belinskii, Apollon Grigor'ev, Nikolai Stankevich, Alexander Herzen, Mikhail Bakunin, and others. While the creativity of Russian authors has never been questioned by outside observers and critics, the intellectual output of Russia's first professional critics and philosophers, when judged against the background of West European traditions, especially the German one, which had a seminal influence on the Russian thinkers of the 1840s, is sometimes deemed derivative and lacking in rigor. ${ }^{2}$ This opinion is not entirely fair insofar as it implies the existence of a universal academic standard. As representatives of a culture that only recently entered a dialogue with the European civilization, these Russian intellectuals could not have been wholly assimilated into the European intellectual and academic milieu. Their main legacy consisted in expanding the realm of ideas and promoting the principle of individuality

\footnotetext{
1 Lotman (1992), 310-314.

2 As Isaiah Berlin points out, Belinskii who did not know German and was always too much under pressure to publish to be able to refine his ideas and polish his works, was particularly vulnerable to such criticism. See Berlin (1978), 183. While being rather sympathetic to Belinskii (despite his shortcomings), Berlin is quite critical of the populists of the 1860 s and 1870 s, whose ideas he deems completely unoriginal. Ibid., 210.
} 
in a semi-feudal society that was only beginning to embrace such Western values as freedom of conscience, intellectual curiosity, and creativity. Along with their fellow creative artists, these thinkers came to be instrumental in shaping the "intelligentsia" as a new meritocratic caste that opposed itself to the traditional hierarchies based on social origins, official rank, and wealth. Consequently, their role in the development of the revolutionary movement can hardly be overestimated.

The phenomenon of the intelligentsia has been for decades one of the central topics in Russian historiography. ${ }^{3}$ As is often the case with popular topics, there have emerged a number of habitual ideas and formulations. Thus intelligentsia is usually perceived as vehemently anti-religious, scientifically (that is to say, positivistically) minded, and prone to fanaticism. As the authors of The Signposts [Vekhi] claimed in 1909, it was the radical intelligentsia, Russia's self-appointed savior and martyr, that could be blamed for the political inertia and immaturity of the rest of society, which precipitated the 1905 revolution. ${ }^{4}$ Of course, serious students of Russian history realize that the tragedy of 1905 and subsequent revolutions could not be blamed on the intelligentsia and intellectuals alone, but had many global economic and political causes. Nevertheless, the radicals continue to be perceived as the most forceful faction whose role in the political crises of the 1900s was decisive. Scholars who share this opinion forget that a genuine intellectual elite can never be a wholly homogeneous group, because homogeneity undermines self-consciousness and breeds dogmatism. Indeed, the essays in The Signposts make it clear that the unflattering image of an intelligent as a crude thinker fanatically dedicated to his ideals emerged as a result of self-critical discussions among the intellectuals.

Self-criticism, which accompanies the development of autonomous consciousness, has been part and parcel of the intelligentsia's spiritual life since the appearance of Chaadaev's First Philosophical Letter. At certain points the ideological polemics polarized the public sphere to such an extent that no consensus seemed ever possible. Yet, arguably, these very crises (such as, for example, the split within the editorial board of The Contemporary in 1856/7, the critical polemics aroused by the publication of Turgenev's Fathers and Sons, or the scandal caused by Tolstoy's attacks on bourgeois moral and aesthetic values in the $1870 \mathrm{~s}-1880$ s) were symptomatic of the growing strength and influence of the intelligentsia in society. In the post-Soviet period we are witnessing a similar crisis, marked by a resurgence of old debates concerning individualism versus collectivism, nationalism versus cosmopolitanism, secularism versus religion, feminism versus traditional gender roles, etc., as well as by the emergence of some new debates concerning the role of information and biotechnology in life and art. In my opinion, the intensity of these debates testifies to the vitality of the literary public sphere and the renewed presence of the intelligentsia.

The essays included in this special issue reflect this contemporary debate, in which canonical and well-known figures are placed in new constellations and

\footnotetext{
3 See, Berlin (1978), Frede (2011), Malia (1960), Raeff (1966) and Riasanovsky (1957).

4 Vekhi (2017). See, in particular, Mikhail Gershenzon's, Pyotr Struve's and Semyon Frank's contributions to this collection.
} 
viewed in a new light. Thus Julia Mehlich brings out the ludic dimension of the Russian revolution by comparing it to the German revolution of 1918. The Bohemians she discusses-Andrei Bely, Fyodor Stepun, Kurt Eisner, and Victor Klemperer-were all intellectually indebted to Romanticism. Their buoyant, almost carnivalesque careers during the turbulent revolutionary years bring home deep-seated similarities between the Russian intelligentsia and the German Bildungsbürgertum. These thinkers' moral and psychological resilience manifested through their capacity for self-reinvention was anchored in their powerful selves with their boundless propensity for Romantic irony. The Russian intellectuals' filiation with the German philosophical tradition and its ideal of aesthetic education of humanity is also central to Lina Steiner's essay. She argues that Schiller's vision of the beautiful soul underlies the aesthetic and ethical architectonics of Tolstoy's War and Peace. Furthermore, she suggests that Tolstoy's interest in Schiller could have been prompted by his dialogue with Herzen, who was a lifelong devotee of the German poet. Throughout the rest of his career Tolstoy continued his search for an ethically and aesthetically developed human type, which he linked to the idea of revolution as an inner spiritual reform.

The majority of Russian thinkers in the second half of the nineteenth century shared Tolstoy's Chiliastic dreams. However, many of them were disappointed in the kind of secular humanism we find in Schiller and Tolstoy. Hence various symbolist and post-symbolist attempts to replace aesthetic education or Bildung with various mystical and spiritualistic doctrines. Vladimir Marchenkov's essay reexamines Nikolai Berdyaev's doctrine of theurgy put forth in his 1916 book The Meaning of Creative Act. As Marchenkov points out, this doctrine remains relevant for contemporary philosophy of art insofar as it highlights the problem of the ludic nature of art, which Schiller had analyzed in his Letters on Aesthetic Education of Mankind. Taking a cue from Schiller, Marchenkov argues that the ludic ontology constructed by art, is quite distinct from the non-ludic ontology. The true lesson of the ludic aesthetic experience is to recognize reality for what it is and to keep it distinct from the frank illusions of art. A thinker reared in the mystical atmosphere of the Russian Silver Age, Berdyaev refused to believe that the enlargement of human mind through play constitutes the ultimate end of art. His doctrine of theurgy signaled a decisive parting of the ways between Berdyaev (and other religious philosophers of his generation) and their Marxist contemporaries, many of whom subscribed to the Schillerian view of art.

A yearning for a new religion that could restore a sense of purpose to individual lives and community was shared by many artists and thinkers on the eve of the 1917 Revolution. However, there was a world of difference between Tolstoy's humanistic call for an anti-dogmatic Christianity on the one hand and the religious revival advocated by thinkers like Berdyaev. We can get a sense of the breadth and diversity of the Russian literary public sphere at this historical juncture when we turn to Dagmar Mironowa's essay which compares Tolstoy's and Gorky's visions of historical and cultural progress as expressed in their fiction and non-fiction. Despite differences in age, social background and education, the two authors are remarkably close when it comes to their vision of human being's place in nature and history. Indeed, Gorky's Nietzsche-inspired God-building is a not-so-distant relation of 
the Romantic humanism which had inspired Herzen, Tolstoy, and a number of other Russian intellectuals from the aristocratic and middle class backgrounds earlier in the century.

The continuity between this earlier phase dominated by the Westernized gentry and middle-class intelligentsia and the later phase marked by the emergence of genuinely popular authors from the working class provides evidence of remarkable cultural advance in a society whose level of literacy grew dramatically since the 1860s. Whether this cultural evolution could have gradually transformed Russia into a bourgeois democracy on par with West European countries had the Bolsheviks not intervened in 1917 remains an unanswered and perhaps unanswerable question. While alternative scenarios are thinkable, the one that played itself out was more complex than any single narrative or literary genre can encompass. The collapse of the Romanov Empire led to a veritable cultural explosion, which destroyed the old values and set off a painful process of building a new society and a new culture. While some talented thinkers and authors survived the crucible of the revolution and even thrived in this turmoil, many others were pushed into exile or fell victim to wars, Stalinist terror, and ideological brainwashing. The history of the Soviet cultural experiment propelled by the 1917 Revolution remains one of the hottest topics in contemporary historiography. Indeed, a better understanding of both the phenomenon of the revolution itself and its far-reaching consequences and long-lasting effects is the most urgent task for all scholars of Russian culture, because without such an understanding we cannot find our bearings in the complex and rapidly changing contemporary sociopolitical and cultural environment. While the essays assembled in this special issue cannot claim to provide a comprehensive analysis or even a comprehensive survey of relevant thinkers and topics, we hope that they offer interesting perspectives and will provoke further discussion.

\section{References}

Berdiaev, N. A., et al. (2017). Vekhi: Sbornik statei o russkoi intelligentsii. Moscow: Ripol Klassik.

Berlin, I. S. (1978). Russian thinkers. London: Hogarth Press.

Frede, V. (2011). Doubt, atheism, and the nineteenth-century Russian intelligentsia. Madison: The University of Wisconsin Press.

Lotman, Y. (1992). Dekabrist v povsednevnoi zhizni. Izbrannye stat'ii, 1, 296-336.

Malia, M. (1960). What is the intelligentsia? Daedalus, 89(3), 441-458.

Raeff, M. (1966). Origins of the Russian intelligentsia: The eighteenth-century nobility. New York: Harcourt, Brace and World.

Riasanovsky, N. V. (1957). Some comments on the role of the intelligentsia in the reign of Nicholas I of Russia, 1825-1855. The Slavic and East European Journal, 15(3), 163-176.

Publisher's Note Springer Nature remains neutral with regard to jurisdictional claims in published maps and institutional affiliations. 